\title{
GOING 'BEYOND MICROFINANCE': ENHANCING ISLAMIC MICROFINANCE PROGRAMMES IN BANGLADESH
}

\author{
Tawfique Al-Mubarak ${ }^{*}$
}

\begin{abstract}
Microfinance programmes have been operating in Bangladesh since the early seventies. With the Bangladesh Rural Advancement Committee (BRAC) and the Grameen Bank (GB) as the pioneers, many other Non Governmental Organizations (NGOs) and Microfinance Institutes (MFIs) have grown up to provide banking services to the 'bankless' poor of the society. Most of these MFIs disburse cash loans, and in most cases at a high rate of interest. Of course, interest as riba is among the gravest of prohibitions in Islam. Besides, a majority of the clients who take such microfinance loans often live below the poverty level, and have their own priorities to meet before investing the loan in a profit-bearing investment. As a result, the loans turn out to be consumption loans without resulting in any profit to pay the interest therefrom. In the long run, the clients fall into the 'debt-trap' and get poorer. This paper suggests that if instead of disbursing cash facilities, the clients were provided with employment under specific projects of which some portions could also be sold to them after the project has recovered its capital, poverty eradication ought to become an easier task. This then goes 'beyond microfinance' facilities.
\end{abstract}

\section{Introduction}

Bangladesh has been well recognised for its poverty alleviation programmes and Microfinance Institutions (MFIs) with the Nobel Peace Prize 2006 being awarded to Professor Dr Muhammad Yunus and his brainchild Grameen Bank (GB). However, GB is not the first MFI in the country. Right since independence in 1971, the Bangladesh Rural Advancement Committee (BRAC) was set up with the objective to help the poverty-stricken people of the new nation. Since then, many other MFIs have been initiated and have spread their hands throughout the nation to reach the poor and destitute.

Poverty from an Islamic perspective can be determined from the absence of the five essential 'human needs' as a baseline. These human needs are: (i) Protection of Religion (hifz al-din), (ii) Protection of the self or honor and dignity (hifz alnafs, wal-'ird), (iii) Protection of the intellect or knowledge (hifz al-'aql), (iv) Protection of lineage or offspring (hifz al-nasl), and (v) Protection of property or wealth (hifz al-mal). Fulfilment of these needs can be considered as one of the fundamental purposes of a successful and prosperous life in Islam. Whatever facilitates the fulfilment of these fundamental human needs are considered as utilities or benefits (masalih), and anything that hinders these are considered as 
corruption (mafasid) of the fundamental needs. Sharī' ah scholars have categorised these fundamental human needs among the dharuriyyaat (necessities), in the absence of which a person would be considered poor or deprived of the basic needs. And it hinders him from enjoying a reasonably good and prosperous life. ${ }^{1}$ Therefore, earning a living, access to education and healthcare, or alleviation of poverty all equally fall among the priorities of the objectives of Islamic law (Sharī'ah).

Similarly, Islam discourages excessive wealth and lavishness on one side, and poverty and neglect of basic human needs on the other; rather it encourages towards striking a balanced life. The Prophet (peace be upon him) has advised the Muslims to seek forgiveness from the evils of wealth and also the evils of poverty, on different occasions. ${ }^{2}$ The Prophet (pbuh) used to seek refuge in Allah from poverty. ${ }^{3}$ Similarly, he cautioned that excessive wealth may endanger faith and morality while poverty may lead to disbelief $(k u f r) .{ }^{4}$ However wealth and poverty exist only as a test for the believers. Islam has, therefore, made it an obligatory duty upon the rich to take care of the poor and deprived, as a matter of gratitude and appreciation towards the Lord Almighty for the favours He has bestowed upon them. ${ }^{5}$

Many contemporary Islamic economists have observed that the absence of justice, equality, fair treatment and the fulfilment of basic needs, all equally contribute to poverty. ${ }^{6}$ Therefore, Islamic governance covers the responsibility for eradicating poverty while ensuring justice, equality, fair treatment, and the fulfilment of basic needs.

Poverty is a major concern in many Muslim countries including Bangladesh. Bangladesh is home to more than 56 million of the poor. ${ }^{7}$ Therefore, it is not surprising for the MFIs to hub in Bangladesh. There are 692 MFIs registered up to September 2013 under the Microfinance Regulatory Authority (MRA), and several hundred more applications are awaiting approval. ${ }^{8}$ The conventional MFIs have taken this opportunity to offer loans to the poor with a high interest rate, which often ranges from 15 to 40 percent. ${ }^{9}$ Considering all the related charges like that of documentation of membership fees, and other official costs, the interest rate of the Grameen Bank can be as high as 54.95 percent. ${ }^{10}$

This paper proposes a new means to improve the lives of the poor and the hardcore poor. Learning from the experiences of other poverty alleviating programmes offered by various NGOs and MFIs, the paper mainly addresses a unique programme which would instead of disbursing cash loans, concentrate on enhancing skills, creating employment opportunities, and offer to share the ownership of the project with the employees/target group. Unlike other programmes, this programme aims to uphold the objective of utilising untapped human resources along with the natural resources of the country. 
The model is primarily based on the Islamic concepts of "profit-making with mutual consent'11 and 'mutual cooperation in wellbeing, virtue and righteousness, ${ }^{12}$ which imbeds social responsibility too. It emphasises on the ijaratul- 'aml (hire for wages) concept to alleviate poverty through employment. Thus, it proposes going 'beyond microfinance' by creating employment opportunities for the poor instead of providing cash loans.

\section{Islamic Microfinance: Concept and Principles}

Islam highly encourages charity, while at the same time stresses an emphasis on the believers to minimise their dependency on charity. In a hadith narrated by Hakim ibn Hizam, the Prophet (pbuh) said: "The upper hand (donor's hand) is better than the lower hand (receiver's hand)". ${ }^{13}$ Thus, Islam strongly recommends channelling the flow to the poorest of the poor and the destitute. In another hadith, Ubaidullah Ibn Adl ibn Khiyaar reported that the Prophet (pbuh) highly discouraged giving sadaqah (charity) to two persons at the farewell pilgrimage, but rather encouraged them to earn a living as they both were able bodied, and strong enough to work. ${ }^{14}$ The hadith equally emphasises putting one's own efforts into make a living and being productive, while discourages begging and idly wasting one's skills in vain. Thus, the Prophet (pbuh) emphasised developing human capital and accelerating growth in the society, which fulfils the maqsad of i'mar al-ard - building of human civilisation.

The Islamic MFIs, from a theoretical perspective, provide collateral-free and interest-free loans (qard hasan) unlike many of the conventional MFIs. Besides providing interest-free loans, elements of the social development programmes undertaken by the Islamic MFIs are based on components which directly benefit the poor and needy. It should also ensure distribution of resources and the circulation of wealth from the well-to-do to the weak and deprived in the society as the Qur' an demands. ${ }^{15}$ In fact, the distribution mechanism is built-in within the core spiritual pursuit of Islam.

\section{Problematics of the Conventional MFIs}

Microcredit programmes of leading MFIs, such as Grameen and BRAC along with the many other conventional MFIs and NGOs, have been accused that, even though having being successful in reaching the poor, they have failed to reach the hardcore poor, who are often severely undernourished, marginalised in the society and in poor health or unable to work for various other reasons ${ }^{16}$ Karnani mentioned the high interest rate as a barrier towards alleviating poverty through microloans, which are in reality a trap that entangles a person in the vicious cycle of poverty. ${ }^{17}$ Mannan comments that if all the hidden costs are to be considered, 
GB's interest rate will go as high as 54.95 percent. ${ }^{18}$ Although, most of the conventional MFIs argue that they are charging less than the rates of informal 'money lenders' in the villages, the outcome of both the lenders are same - the exorbitant interest rate makes the poor borrowers poorer. In other words, the MFIs are equally afflicting 'harm' to the poor clients.

Among other criticisms mentioned by Sadeq include issues related to increased family tensions due to excessive women empowerment in a conservative society like that of such as Bangladesh. This has consequently increased divorce rates, and abandonment of hijab (Islamic dress-code), especially in a traditional village setting where hijab is not merely a religious practice, rather a cultural obligation for the women. These have also resulted in a persistent slow cultural de-Islamisation in the long run. ${ }^{19}$

Many of the microcredit providers believe that small amounts of credit can play a vital role in improving the lives and the socio-economic status of these hardcore poor. This may not be true for people who are not economically welloff and have their basic priorities to meet first. The loans taken for an investment often end up as a consumption loan. Hence, they remain vulnerable to extreme poverty, which is likely to grow through the continuous cycle of loans and high interest rates. To pay off the loans with a high interest rate taken from an MFI, they get entrapped in borrowing more and more loans from various MFIs, most of which are not invested in any productive activity.

Besides, most of the MFIs prefer to offer short-term microloans, which create additional pressure on liquidity. Thus, to cover up the high administrative cost, the MFIs charge a higher rate of interest, which ultimately becomes a 'burden' on the poor clients. Another problem is the low rate of return on invested funds. This is due to the fact that a large number of clients take microloans for investing in activities which are widely available in the market, e.g. farming activities, production of basic commodities, transportation, etc. Due to the large number of suppliers and strong competition, return from such investment decreases. As a result, the clients find it hard to strike a balance between the loans taken and the interest to be paid off from the minimum revenues earned. ${ }^{20}$

These people could rather be supported with donations or charity to meet their priority expenses, and basic necessities. Thereafter, they may be trained to improve their skill levels required to engage them in economically productive activities. In fact, the major objectives of the institutions of zakah, awqaf and qard hasan are to alleviate hardcore poverty as a matter of priority, and extend the assistance towards the development of human capital.

It is also true that for the past few years, many organisations have come forward with programmes to reach the 'poorest of the poor' or the hardcore poor in Bangladesh. Such examples may include the World Bank's "Financial 
Services for the Poorest project" (FSP), BRAC's "Targeting the Ultra Poor" (TUP), Proshika's Employment and Income Generating Program (EIGP), GB's loans to the beggars alike. The World Bank's FSP had reached more than 56,000 members, availing to them credit amounting of more than $\$ 2.4$ million until 2005, while BRAC's TUP benefited 285,000 members with credits of up to BDT 1.7 million until 2008. ${ }^{21}$ However, none of these programmes are interest free, which in turn keeps the poorest within the sphere of poverty.

\section{Going ‘Beyond Microfinance’: Basic Concept and Philosophy}

We propose a model to go 'beyond microfinance.' The model is primarily based on the Islamic concepts of 'profit-making with mutual consent'22 and 'mutual cooperation in terms of wellbeing, virtue and righteousness, ${ }^{23}$ which imbeds social responsibility too. Due to the prohibition of interest ( $r i b a)$ in Islam, the model proposes a means for employment which does not require cash loans to be offered to the target group and hence no interest ( $r i b a)$ is involved. It works based on the ju'alah (wage for employment) and/or ijaratul- 'aml (hire for a wage) concept. Here, the 'beyond microfinance' programme offers the capital and the project, while hiring the employee to work in it to earn an income, until the project reclaims its capital with a certain profit, and the ownership of the project can be shared with the employees through providing them the option to buy the ownership shares.

The model proposes that a pool of funding be initiated, which will later be invested into several small-scale projects, whereby the clients will be employed. The pool of the fund may consist of charitable contributions, donations, awqaf, and may also invite investors to take part in raising the capital. The employees employed at the small-scale projects are the target group who come from a very needy and poor background. Thorough market research, a feasibility study, and a risk analysis are necessary before initiating any project. The project would often fund such items, which are widely available in the local market at a reasonable price, and where there is less or no risk involved. Some of these products in the local market may include: farming activities for calves, vegetations, small food stalls, small-scale handicraft industry etc, which are also widely practiced by non-clients of the MFIs. Besides, the project would also ensure marketability of the produced goods. Otherwise, sustainability of the whole model will be in risk. Marketing of the produced goods and items can be enhanced by either joining hands with an existing retailer willing to sell the projects' produce, or by initiating a retail store under the project itself. The latter option could be more complex, yet has the potential to create job opportunities for a larger number of people. Such a retail store would often sell the different produces of several projects within a nearby locality. 
Every project would be under the direct supervision of a project manager who has the skills and knowledge of the project items involved. This ensures that the projects are run properly under a well-trained manager, and not simply left in the hands of the employees. The manager is also responsible to look after the finances, and all specific needs of the project, above all providing from time-totime the required training to the employees, to enhance their working capabilities.

After the project has reached a profit-making stage and recovered the primary capital and the necessary costs involved, the microfinance programme will offer for the employees to buy shares of ownership in the project, if they are interested. The value of the shares could be deducted from the employee's salary, so that they would not have to take the burden of paying cash. As such, the employees would be entitled to own the project together with the microfinance programme and at the same time earn greater profit than before. This would also be an incentive for the employees to work sincerely for the projects of which they also share the ownership.

Besides, the project may allow the employees to keep up their regular dayto-day work that they were involved in prior to joining the projects. Most of the farmers engage in farming only during certain seasons and months of the year, thus they often face seasonal unemployment. These projects will also cater for such people allowing them to keep their regular works and facilitating them to engage in productive activities and overcome the problem of seasonal unemployment.

As a supplementary service, the project may also provide interest-free cash loans, if necessary, to the employees which may be recovered through deducting them from their salary. In this way, it will facilitate them with loans in hand to meet their needs, at the same time assist them to repay the loans from their salaries by which they do not have to bear much risk compared to loans provided by other MFIs.

\section{The ARI-AIM-Mydin Business Transformation Model: A Case Study}

Recently the Accounting Research Institute (ARI) of the Universiti Teknologi MARA (UiTM), Malaysia together with the Amanah Ikhtiar Malaysia (AIM) and Mydin Mohamad Holding Berhad initiated a microfinance model, whereby the microfinance programme has been transformed into business ventures. The microfinance model initiated its programme with financing from AIM to support twenty rural women in setting up a tailoring business in Sungai Pinang, Tanjong Karang. AIM also sponsored the building of a special workshop consisting of sewing machines, cutting benches, display closets, an office and an exhibition room for the tailored baju kurung (local Malaysian ladies' dress). 
The model is supported by the Mydin Mohamad Holding Berhad, a local supply chain hypermarket, which acts as a supplier of the raw materials, as well as the retailer for the ready baju kurung. Here, Mydin plays an important role of marketing the produced goods, which is the most vital source of profit making in the whole model. Since Mydin has its own reputation as an established hypermarket, marketing the produced goods becomes an easy task. With a retailer in the model, it has also guaranteed its sustainability by selling the produced goods. ${ }^{24}$

This is an ingenious model, especially in the sense that it does not directly hand cash to the clients or target group, rather it employs them, and gives them adequate training and develops their skills. In addition to that, it also includes a retailer to assure the sale of produced items in the local market, which ensures sustainability of the model. However, the whole model is a simple employmentbased microfinance model, where the employees have the option to remain in employment for as long as they wish to. This does not however, offer the employees to buy ownership shares of the business model, which we believe would eradicate poverty at a greater pace. However, the employees do have the freedom to offer tailoring services to their individual and corporate customers alongside producing for the retailer (Mydin in this case).

This model, although a unique one, could be further enhanced by adapting the option of selling ownership shares to the employees, at an agreed upon price which could be deducted at a fixed percentage from their monthly salary. In this manner, the employees would end up owning portion of the business, and thus business transformation from microfinance would see the lights on a greater venture.

\section{Conclusions}

Microfinance programmes, which were introduced in Bangladesh forty years ago, still require further enhancement in terms of poverty alleviation, and therefore, their objective of offering a better standard of living has remained beyond reality. More than 40 percent of the people are still under the poverty line, and many do not have access to healthcare, sanitation, safe drinking water and basic nutrition. ${ }^{25}$

These issues are exacerbated with the current political and economic turmoil. However, research shows that major reasons behind such a slow pace of poverty alleviation include: effects of the high interest rate of the credits taken from the conventional MFIs, deprivation from the rights of human development, excessive women empowerment which contributes to family tension in the rural areas, and most notably distancing from developing a balanced life between the spiritual and material aspects. ${ }^{26}$ 
Therefore, it will be more effective to create jobs instead of providing cash loans to people who have no knowledge or skills to do business. Jobs could be created based on local experiences which have already proven to be successful in the country, and hence would minimise the risk of unwanted loss. Besides adapting the 'beyond microfinance' concept, other MFIs or SME banks could also create jobs which are a feasible fit for the local neighbourhood. For example, opening a 'fish processing factory' in a coastal area will avail a large number of people with jobs, contribute to the local economy as well as exports, and increase skills of the employees through their work experience, which they may utilise to establish their own businesses later on. Similarly, small-scale enterprises or industries may grow up to cater for the employment services to many poor households.

As another example, in areas where there is an abundance of coconut trees, one can open up a small industry to produce items and products from the coconut itself. For instance, buttons for clothes and shirts, spoons, and other handicraft items could be produced from the coconut shells. The husks could also be used to make cushions, mats, ropes, hand-art items and other byproducts. The coconut milk, coconut water, and the grinded coconut are all widely used as food items. Especially young coconuts are popular in the major tourist spots.

The 'beyond microfinance' concept can also be imitated in other countries, adapting the local experience of such businesses. Such examples may include small tele-centers, small cattle farms, vegetable farms. We are highly hopeful that one day the 'beyond microfinance' concept would be implemented throughout the world with varieties of projects that suits the local conditions, and eliminate poverty through creating employment.

\section{Policy Recommendations}

- Microfinance Institutions (MFIs) should avoid direct cash disbursement to their clients, rather invest the cash into small businesses and employ them therein.

- Emphasise human capital development by providing training on handy skills, and creative work.

- Develop entrepreneurs from the clients to sustain and enhance small and medium sized enterprises.

- Microfinance projects should also guarantee that their products are well marketed in order to ensure their sustainability.

\section{References}

Al-Quran Al-Karim

Accounting Research Institute (ARI). (2 December 2012). "Collaborative Research on Islamic Microfinance." Available online at: <http://accounting-researchinstitute.blogspot.com/2012/12/collaborative-research-on-islamic.html $>$ Access 
Date: 30 December 2013.

Accounting Research Institute (ARI). (12 June 2013). "Islamic Microfinance: Baju Kurung Handover Ceremony." Available online at: $<$ http://accounting-researchinstitute.blogspot.com/2013/06/islamic-microfinancing-baju-kurung.html > Access Date: 30 December 2013.

Accounting Research Institute (ARI). (26 August 2013). "Microcredit Business Transformation." Available on <http://accounting-research-institute.blogspot. com/2013/08/microcredit-business-transformation.html $>$ Access Date: 30 December 2013.

Al-Bukhary, Ismail. (1422H.). Sahih Al-Bukhary. Edited by M. Zuhair bin Naser. N. p.: Dar Tuq al-Najat.

Alhabshi, Othman. (n.d.). Poverty eradication from Islamic perspectives. Available at: <http://elib.unitar.edu.my/staff-publications/datuk/JOURNAL.pdf> Access Date: 10 September, 2009.

Al-Mubarak, Tawfique. (2009). Rural Development Scheme (RDS) of the Islamic Bank Bangladesh Limited (IBBL): A Case Study of an Islamic Microfinance Project. Unpublished MA dissertation, Markfield Institute of Higher Education, Leicester, UK.

Amin S., Rai, A.S. and Ropa, G. (2003). "Does microcredit reach the poor and vulnerable? Evidence from Northern Bangladesh". Journal of Development Economics, (vol. 70), 59-82.

BRAC. (2009). BRAC annual report 2008. Dhaka: BRAC.

Chapra, M.U. (1980). "Islamic welfare state and its role in economy," in Ahmad, Khurshid (Ed.), Studies in Islamic Economics. Leicester: Islamic Foundation UK.

Chapra, M.U. (1985). Towards a just monetary system. Leicester: Islamic Foundation UK.

Chapra, M.U. (1992). Islam and the economic challenge. Leicester: Islamic Foundation UK and Herndon, Virginia: International Institute of Islamic Thought.

Hassan, M. Kabir. (2010). An Integrated Poverty Alleviation Model Combining Zakat, Awqaf and Microfinance. Paper presented at the Seventh International Conference - The Tawhidic Epistemology: Zakat and Waqf Economy, Bangi, Malaysia, pp. 261-281.

Hulme, David, and Mosley, Paul. (1996). Finance against poverty. London: Routledge.

Karnani, Aneel. (2007). “Microfinance misses its mark". Stanford Social Innovation Review, (Summer), 34-40.

Mannan, M.A. (2007). Alternative Microcredit Models in Bangladesh: A Comparative Analysis between Grameen Bank and Social Investment Bank and Myths and Realities. Paper Presented in First International Islamic Conference on Inclusive Islamic Financial Sector Development: Enhancing Islamic Financial Services for Micro and Medium Sized Enterprises (MMES) on April 17-19, 2007, Brunei Darussalam.

Microfinance Regulatory Authority (MRA). (2013). List of Licensed MFIs as of 02 September 2013. Available at: <http://www.mra.gov.bd/images/Licensed_NGO_ MFIs/0001-692\%2002-09-13\%20\%20english.pdf $>$ Access Date: $14^{\text {th }}$ September 2013. 


\section{Notes}

* Tawfique Al-Mubarak is a Research Fellow at International Institute of Advanced Islamic Studies, Malaysia. The author is thankful to Dr Tazul Islam for his insights on the concept behind this paper.

1. Othman Alhabshi, Poverty Eradication from Islamic Perspectives, available online at: <http://elib.unitar.edu.my/staff-publications/datuk/JOURNAL.pdf>, Access Date: 10 September 2009, pp. 3-7.

2. Sahih Al-Bukhary, Hadith no.: 6377.

3. Al-Nasa'i, Hadith no.: 1347.

4. M. N. Siddiqi, "The guarantee of a minimum level of living in an Islamic state," in Iqbal, Munawar (Ed.), Distributive justice and need fulfillment in an Islamic economy, (Leicester, Islamic Foundation UK, 1988) pp. 251-86.

5. Al-Qur'an, Surah al-Dhariyat (51): 19; and Surah al-Ma'arij (70): 24-25.

6. M. N. Siddiqi, 251; M. Umar Chapra, Islam and the economic challenge, (Leicester, Islamic Foundation UK and Herndon, Virginia, International Institute of Islamic Thought, 1992), 209, and M. Umar Chapra, Towards a just monetary system (Leicester, Islamic Foundation UK, 1985).

7. World Bank, "Poverty assessment for Bangladesh: Creating opportunities and bridging the East-West divide," Bangladesh development series (26), (Dhaka, The World Bank office, 2008) p. xiv.

8. Microfinance Regulatory Authority, List of Licensed MFIs as of 2 September 2013, available online at: <http://www.mra.gov.bd/images/Licensed_NGO_ MFIs/0001-692\%2002-09-13\%20\%20english.pdf> accessed on: 14 September 2013.

9. M. Mizanur Rahman, "Rural People's Moral and Ethical Development through Islamic Micro-finance Program and its Impact on their Poverty Alleviation," paper presented at the International conference on Islamic Banking and Finance: Ethics and Financial Practices in Global Perspective, organised by the National Centre for Excellence in Islamic Studies, University of Melbourne, Australia, November 19-20, 2008, p.3.

10. M.A. Mannan, "Alternative Microcredit Models in Bangladesh: A Comparative Analysis between Grameen Bank and Social Investment Bank and Myths and Realities," paper presented at the First International Islamic Conference on Inclusive Islamic Financial Sector Development: Enhancing Islamic Financial Services for Micro and Medium Sized Enterprises (MMES) held in Brunei Darussalam on April 17-19, 2007, p.3.

11. Al-Qur'an, Surah Al-Nisa (4):29.

12. Al-Qur'an, Surah Al-Ma'idah (5):2.

13. Sahih Al-Bukhary, Hadith no.: 1427.

14. Sunan Abi Dawud, Kitabuz-Zakah, Book: 9, Hadith no: 1629.

15. Al-Qur'an, Surah al-Hashr (59): 7.

16. S. Amin, A. S. Rai, and G. Ropa, "Does microcredit reach the poor and vulnerable? Evidence from Northern Bangladesh", Journal of Development Economics, (vol. 70), 2003, 59-82; also David Hulme, and Paul Mosley, Finance against poverty, (London, Routledge, 1996). 
17. Aneel Karnani, "Microfinance misses its mark," Stanford social innovation review, (summer, 2007), 34-40.

18. M. A. Mannan, "Alternative Microcredit Models in Bangladesh: A Comparative Analysis between Grameen Bank and Social Investment Bank and Myths and Realities."

19. Tawfique Al-Mubarak, Rural Development Scheme (RDS) of the Islamic Bank Bangladesh Limited (IBBL): A Case Study of an Islamic Microfinance Project (Unpublished MA dissertation, Markfield Institute of Higher Education, Leicester, UK, 2009), p. 39.

20. M. Kabir Hassan, An Integrated Poverty Alleviation Model Combining Zakat, Awqaf And Microfinance, paper presented at the Seventh International Conference - The Tawhidic Epistemology: Zakat and Waqf Economy, Bangi, Malaysia, 2010, pp. 271-272.

21. World Bank, "When Microcredit Isn't Enough: Bangladesh Poor Get a Chance to Move Up," available online at: <http://go.worldbank.org/FWETFG1JX0> (3 May 2005, accessed on: 16 August 2009); and see BRAC, BRAC Annual Report 2008 (Dhaka, BRAC, 2009), p. 7.

22. Al-Qur'an, Surah al-Nisa (4): 29.

23. Al-Qur'an, Surah al-Maidah (5): 2.

24. For further information on the Business Transformation Model, visit: Accounting Research Institute (ARI), "Collaborative Research on Islamic Microfinance," available online at: <http://accounting-research-institute. blogspot.com/2012/12/collaborative-research-on-islamic.html $>$ (2 December 2012, accessed on 30 December 2013); ARI, "Islamic Microfinance: Baju Kurung Handover Ceremony," available online at: $<\mathrm{http}$ ://accounting-researchinstitute.blogspot.com/2013/06/islamic-microfinancing-baju-kurung.html > (12 June 2013, accessed on 30 December 2013); and ARI, "Microcredit Business Transformation," available on <http://accounting-research-institute.blogspot. com/2013/08/microcredit-business-transformation.html> (26 August 2013, accessed on 30 December 2013).

25. World Bank, "Poverty assessment for Bangladesh: Creating opportunities and bridging the East-West divide," Bangladesh development series (26), (Dhaka, The World Bank office, 2008).

26. A. H. M. Sadeq, M. Kabir Hassan, and Dewan A.H. Alamgir, Microfinance Services and Poverty alleviation in Bangladesh. A Comparative Analysis of Secular and Islamic NGOs, Paper Presented at the Fourth International Conference on Islamic Economics and Banking: Islamic Finance-Challenges and Opportunities in the Twenty-First Century, organised by International Association for Islamic Economics; IRTI-IDB, The Islamic Foundation UK and the Loughborough University, held on August 13-15, 2000, at Loughborough University, UK. 